\title{
Pengaruh Economic Value Added, Profitabilitas, Leverage, dan Earning Per Share terhadap Return Saham \\ Pada Perusahaan Oil dan Gas Periode 2011 -2016
}

\author{
Rd. Qoyyimatul Fitriah W \\ E-mail: airizalmahyra@gmail.com \\ Universitas Negeri Jakarta
}

\begin{abstract}
This study aims to determine the economic value influence, profitability, leverage, and earnings per share on returns to oil \& amp; gas period 2011-2016 which is explained systematically about the facts and the nature of an object in the study then merges the variables associated with it with the presentation of secondary data from the financial statements of Oil and Gas companies in Indonesia, the population used in this study the Oil and Gas companies listed on the stock exchange in the period of 2011 to 2016. The samples used in this study were 8 Oil and Gas companies in Indonesia, using the purpose purpose sampling method to obtain representative samples that fit the criteria already confirmed. In this study, the data analysis method used is panel data (pooled data) which is a combination of data between times (time series) and data between individuals or spaces (cross section) in Oil and Gas companies in Indonesia. The results of the study show that Simultaneously or together the independent variables included in this study, namely EVA, ROI, ROA, ROE, DER and EPS affect the return of shares of oil and gas companies in Indonesia. This can be seen from the probability of the F-statistic of 0.00 being below the value of 0.05 . Adjusted $R$ square value in this model is 0.366 percent which means that the variation of stock returns which can be explained by the independent variables included in this model is 36.60 percent.
\end{abstract}

Keywords: Economic Value Added, Profitability, Leverage, and Earning Per Share Against Stock Returns in Oil \& Gas Companies

\begin{abstract}
Abstrak
Penelitian ini bertujuan untuk untuk mengetahui pengaruh economic valueadded, profitabilitas, leverage, dan earning per share terhadap return sahampada perusahaan oil \&amp; gas periode 2011 -2016 yang di jelaskan secara sistematis tentang fakta-fakta serta sifat dalam suatu objek dalam penelitian kemudian melakukan penggabungan antar variabel yang terkait di dalamnya dengan penyajian data sekunder dari laporan keuangan dari perusahaan Oil dan Gas di negara indonesia, Populasi yang di gunakan pada penelitian ini adalah perusahaan Oil dan Gas yang terdaftar di bursa efek kurun waktu 2011 sampai 2016. Sampel yang di gunakan dalam
\end{abstract}

Jurnal Ilmiah Al Tsarwah

Program Magister Program Studi Ekonomi Syariah

Institut Agama Islam Negeri (IAIN) Bone 
penelitian ini sebanyak 8 perusahaan Oil dan Gas di negara indonesia, dengan menggunakan metode purpose sampling tujuanya untuk memperoleh sampel representatif yang sesuai kriteria yang sudah di pastikan. Pada penelitian ini, metode analisa data yang digunakan adalah data panel (pooled data) yang merupakan gabungan dari data antar waktu (time series) dan data antar individu atau ruang (cross section) di perusahaan Oil dan Gas di negara indonesia.hasil penelitian menunjukkan bahwa secara simultan atau bersama-sama variabel-variabel bebas yang dimasukkan dalam penelitian ini yaitu EVA, ROI, ROA, ROE, DER dan EPS mempengaruhi return saham perusahaan minyak dan gas di Indonesia. Hal ini terlihat dari probabilitas F-statistik sebesar 0,00 berada di bawah nilai 0,05 . Nilai adjusted $R$ square pada model ini sebesar 0,366 persen artinya bahwa variasi dari return saham yang dapat dijelaskan oleh variabel bebas yang dimasukkan ke dalam model ini sebesar 36.60 persen .

Kata Kunci : Economic Value Added, Profitabilitas, Leverage, Dan Earning Per Share Terhadap Return Saham Pada Perusahaan Oil \&amp;Gas

\section{PENDAHULUAN}

Indonesia saat ini tengah menghadapi momen krusial akan tetapi Indonesia sedang melakukan berbagai perubahan untuk memenuhi tuntutan yang terus meningkat serta konsumsi lebih dari 250 juta pendudukannya terhadap kebutuhan OIL \& GAS. Pertumbuhan Indonesia yang stabil pada rentang 5-6 persen pertahun membutuhkan pasokan energi yang dapat diandalkan dan berkelanjutan juga. Pada titik balik di bidang sosial dan ekonomi ini, industri OIL \& GAS diatur sedemikian rupa untuk memainkan peran utama yang dipimpin oleh pemerintah dengan tujuan untuk mengatasi masalah-masalah kronis yang memperlambat pertumbuhan salah satu dari 20 negara teratas penghasil OIL \& GAS ini. Kendati demikian, sejak pertengahan 2014, harga minyak dunia mulai menurun tajam karena lambatnya aktivitas perekonomian dunia. Pada bulan febuari 2016 harga minyak sentuh titik terendah selama 13 tahun. Namun, setelahnya mulai pulih.

Pasar modal memiliki peran penting bagi industri migas dalam menunjang perekonomian suatu Negara. Pasar modal merupakan suatu sarana yang dapat dimanfaatkan untuk memobilisasi dana, baik dari dalam maupun dari luar negeri. Pasar modal bagi investor merupakan wahana untuk menginvestasikan dananya, dan fungsi ekonomi dari pasar modal adalah dengan menyediakan fasilitas dengan 
mempertemukan dua kepentingan antara pihak yang memiliki kelebihan dana (investor) dengan pihak yang memerlukan dana (emiten). Investor dalam menanamkan dananya di pasar modal tidak hanya bertujuan dalam jangka pendek tetapi juga bertujuan untuk memperoleh pendapatan dalam jangka panjang dan dengan harapan mendapatkan keuntungan dimasa yang akan datang berupa capital gain dan deviden yield. Pada saat investor akan melakukan investasi tersebut, investor harus memastikan terlebih dahulu apakah modal yang ditanamkan mampu memberikan pengembalian (return) yang diharapkan, yaitu dengan cara mengetahui kinerja perusahaan, hal ini memungkinkan aktifitas perekonomian menjadi meningkat karena perusahaan dapat meningkatkan pendapatnya dan pada ahirnya akan memberikan kemakmuran bagi masyarakat lebih luas.

Calon investor memerlukan informasi mengenai kemampuan perusahaan dalam menghasilkan laba yang dapat dilihat dari return yang diterima oleh investor dan melihat bagaimana perusahaan mengelola asetnya. Apabila dana tersebut dapat dikelola dengan baik maka akan dapat meningkatkan laba yang diperoleh sehingga return yang dihasilkan akan meningkat pula. Return adalah apa yang diperoleh investor dari investasinya dalam suatu periode yang dalam hal saham berupa dividen dan untung capital (capital gain) yaitu kenaikan nilai investasi (Suwardjono, 2005). Pada saat investor akan melakukan investasi tersebut, investor harus memastikan terlebih dahulu apakah modal yang ditanamkan mampu memberikan pengembalian (return) yang diharapkan, yaitu dengan cara mengetahui kinerja perusahaan. Dimana setiap perusahaan bertujuan memaksimalkan kekayaan pemegang saham. Pengukuran kinerja perusahaan diperlukan untuk menentukan keberhasilan dalam mencapai tujuan tersebut.

Pengukuran kinerja keuangan berdasarkan laporan keuangan banyak dilakukan dengan menggunakan alat ukur kinerja yang berbeda. Salah satu cara untuk mengetahui kinerja keuangan suatu perusahaan dapat dilakukan dengan melakukan analisis terhadap laporan keuangannya.

Nilai perusahaan dapat diketahui dengan mengukur kinerja perusahaan. Pengukuran kinerja perusahaan dengan menggunakan rasio-rasio keuangan 
perusahaan seperti rasio likuiditas, rasio leverage dan rasio profitabilitas. Tetapi penggunaan analisis rasio keuangan sebagai alat ukur akuntasi konvesional memiliki kelemahan utama yaitu mengabaikan adanya biaya modal, sehingga sulit untuk mengetahui apakah suatu perusahaan telah berhasil menciptakan nilai atau tidak. Kelemahan itu dapat teratasi dengan konsep Economic Value Added. Konsultan Stern Stewart Management service di Amerika Serikat dari perusahaan Stern Steward \& co pada tahun 1993 mengembangkan suatu konsep yaitu Economic Value Added. Economic Value Added atau nilai tambah ekonomis merupakan pendekatan dalam menilai kinerja perusahaan dengan memperhatikan ekspektasi penyandang dana. Economic Value Added mengukur nilai tambah yang dihasilkan (value creation) suatu perusahaan dengan cara mengurangi beban biaya modal (cost of capital) yang timbul sebagai akibat investasi yang dilakukan, karena menurut Dodd dan Chen (1996) Economic Value Added dan Market Value Added telah dipilih sebagai alat ukur kinerja perusahaan dengan keyakinan bahwa Economic Value Added mengkolerasikan antara kinerja manajemen dengan return saham, selain itu dibandingkan dengan pengukuran kinerja lainnya seperti Return on Capital (ROC), Return on Equity (ROE), Earning per Share (EPS), dan pertumbuhan cash flow secara sistematik mempunyai korelasi yang lebih tinggi dalam menciptakan nilai bagi para pemegang saham.

Penelitian yang dilakukan oleh Anggrahini (2014) yang meneliti ROI,ROE,EPS dan EVA terhadap return saham, memberikan hasil dapat ditarik beberapa kesimpulan yaitu Return on equity berpengaruh tidak signifikan. Secara parsial ReturnOn Investment $(R O I)$ berpengaruh secara signifikan terhadap return saham perusahaan manufaktur.Earning per share berpengaruh signifikan terhadap returnsaham pada perusahaan manufaktur.Economic Value Added (EVA)berpengaruh tidak signifikan atau dengan kata lain tidak berpengaruh terhadap returnsaham pada perusahaan manufaktur.Sedangkan secara simultan ROI, ROE, EPS dan EVA berpengaruh signifikan terhadap return saham perusahaan manufaktur.

Hasil penelitian Ansori (2015) mengenai pengaruh Economic Value Added (EVA) dan Market Value Added (MVA) terhadap return saham pada perusahaan manufaktur yang terdaftar di bursa efek indonesia memberikan hasil yang dapat ditarik 
kesimpulan yaitu EVAberpengaruh positif dan signifikan terhadap return saham dan MVA juga berpengaruh positif dan signifikan terhadap return saham.

Hasil dari penelitian Pulugan \& Yunita (2015) mengenai pengaruh return on assets, return on equity, dan debt to equity ratio terhadapterhadap returnsaham pada perusahaan Garuda Indonesia. Teknik analisis yang digunakan adalah teknik analisis regresi linier berganda menyimpulkan bahwa nilai rasio $R O A, R O E$ dan $D E R$ tidak berpengaruh secara simultan terhadap Return saham. Secara parsial masing-masing variabel independen tidak berpengaruh terhadap variabel dependen.

Hasil dari penelitian Puspitadewi \& Rahyuda (2016) mengenai pengaruh $D E R, R O A, P E R$ dan EVA terhadap Returnsaham pada perusahaan Food and Beverage di BEI. Teknik analisis yang digunakan adalah teknik analisis regresi linier berganda menyimpulkan bahwa variabel ROA dan PER berpengaruh positif dan signifikan terhadap Return saham, sementara variabel lainnya memiliki pengaruh yang tidak signifikan terhadap return saham.

Dari pengujian-pengujian yang telah dilakukan oleh berbagai peneliti terdahulu masih terjadi perbedaan hasil penelitian (research gap) mengenai kinerja keuangan perusahaan yang berpengaruh terhadap returnsaham dan untuk melihat pentingnya rasio keuangan bagi investor yang tidak berspekulasi dalam menjatuhkan pilihannya terhadap suatu saham. Karena tidak semua kinerja keuangan mempunyai pengaruh yang positif dan signifikan terhadap returnsaham, selain itu juga bisa dijadikan tolak ukur dalam mengambil keputusan investasi misalnya terjadinya krisis atau faktor ekonomi lainnya. Dalam penelitian ini peneliti hanya menggunakan analisis laporan keuangan yang dapat mengukur kinerja keuangan perusahaan dengan menggunakan Economic Value Added, Return On Investments, Return On Assets, Return On Equity, Debt to Equity Ratio dan Earning Per Share untuk melihat kondisi keuangan yang terjadi di perusahaan terhadap returnsaham.

Berdasarkan latar belakang diatas maka penulis tertarik untuk melakukan penelitian dengan judul "Pengaruh Economic Value Added, Profitabilitas, Leverage, Dan Earning Per Share Terhadap Return Saham Pada Perusahaan Oil \& Gas Periode 2011 -2016". 
Berdasar pada uraian-uraian yang telah dipaparkan, maka permasalahan pokok yang dijadikan obyek bahasan Apakah Economic Value Added berpengaruh terhadap returnsaham pada perusahaan OIL \& GAS yang listing dalam BEI, Apakah Return on Investment berpengaruh terhadap returnsaham pada perusahaan OIL \& GAS yang listing dalam BEI dan Apakah Return on Asset berpengaruh terhadap returnsaham pada perusahaan OIL \& GAS yang listing dalam BEI?

\section{HIPOTESIS}

Ho : Economic Value Added (Eva), Return On Investement (Roi), Return On Assets (Roa), Return On Equity (Roe), Debt To Equity Ratio (Der) Dan Earning Per Share (Eps) Tidak Berpengaruh terhadap return saham

Ha : Economic Value Added (EVA), Return On Investement (ROI), Return On Assets (ROA), Return On Equity (ROE), Debt To Equity Ratio (DER) Dan Earning Per Share (EPS) Berpengaruh terhadap return saham

\section{METODE}

\section{Unit Analisis dan Ruang Lingkup Penelitian}

\subsection{Objek Penelitian}

Objek sampel data dalam penelitian ini menggunakan data sekunder dari laporan keuangan perusahaan tahunanpada perusahaan OIL \& GAS periode 2011 sampai 2016.

\subsection{Tempat penelitian}

Tempat penelitian yang akan di lakukan penulis berada pada lingkup perusahaan OIL \& GAS yang terdaftar di Bursa Efek di negara Indonesia, dalam kurun waktu tahun 20112016.

\subsection{Bidang Penelitian}

Bidang penelitian ini yang akan di lakukan penulis yakni di profitabilitas perusahaan OIL \& GAS di Bursa Efeknegara Indonesia,di peroleh dari annual financial perusahaan 
OIL \& GASterdaftar dalam Bursa Efek di negara Indonesia dalam kurun waktu tahun 2011-2016.

\subsection{Waktu Penelitian}

Dalam penelitian waktu yang di gunakan penulis selama 6 bulan tahun ajaran 2017/2018 Program Studi Magister Manajemen Pascasarjana Universitas Negeri Jakarta.

\subsection{Metode Penelitian}

Dalam penelitian ini, metode yang akan di gunakan ialah metode penelitian kuantitatif yang tujuanya untuk mengerjakan suatu yang di jelaskan secara sistematis tentang fakta-fakta serta sifat dalam suatu objek dalam penelitian kemudian melakukan penggabungan antar variabel yang terkait di dalamnya.

Melalui konsep tersebut yang di atas, bisa di simpulkan jika metode kuantitatif ialah metode yang memiliki tujuan dalam mendeskripsikan benar atau salahnya terhadap fakta yang di miliki serta adanya pemberitahuan tentang korelasi setiap variabel yang di teliti melalui cara pengumpulan data,menganalisis data, serta menjelaskan data tersebut melalui pengujian hipotesis statistik.

Melalui penelitian model terebut di gunakan agar bisa menganalisis pengaruh variabel bebas terhadap variabel terikat. Variabel independent yang di gunakan dalam penelitian ini Economic Value Added, Profitabilitas, Leverage, Dan Earning Per ShareSedangkan variabel dependent ialah return saham.

\subsection{Operasional Variabel Penelitian}

Sesuai judul penelitian ini yaitu "PENGARUH ECONOMIC VALUE ADDED, LEVERAGE, EARNING PERSHARE TERHADAP RETURN SAHAM PADA PERUSAHAAN OIL\&GAS DI BURSA EFEK INDONESIA PERIODE 2011 - 2016", maka terdapat beberapa variabel dalam penelitian ini, yaitu :

1. Variabel terikat $(\mathrm{Y})$ atau dependent variabel yaitu variabel yang nilainya bergantung pada nilai variabel lain. Variabel terikat pada penelitian ini adalah returnsaham. Dimana untuk menghitung returnsaham menggunakan rumus sebagai berikut : 


\section{Return saham $=\underline{\mathrm{Pt}-\mathrm{Pt}-1}$ \\ Pt -1}

Dimana :

Pt $\quad$ : Harga saham pada periode $t$

Pt -1 : Harga saham pada periode t-1

2. Variabel bebas $(X)$ atau independent variabel yaitu variabel yang nilainya tidak bergantung nilai variabel lain. Variabel bebas dalam penelitian ini adalah :

a. Economic Value Added (EVA)

Economic Value Added merupakan pengukuran total faktor kinerja karena perhitungan Economic Value Addedtelah memasukan semua unsur yang ada dalam laporan laba/rugi dan neraca. Dimana perhitungan Economic Value Added adalah :

$E V A=\{E B I T(1-T A X)\}\{$ invested capital X WACC $)\}$

Capital Charges : WACC x Capital Invested

- Untuk menghitung WACC:

$W A C C=\mathrm{Wd} \cdot \mathrm{Kd}(1-\mathrm{T})+\mathrm{We} \cdot \mathrm{Ke}$

- Menghitung Cost of Debt (Kd)

$\mathrm{Kd}=\underline{\text { Total Interest Expenses }}$

Long Term Debt

Menghitung Cost of Common Equity (Ke)

$\mathrm{Ke}=\mathrm{E}(\mathrm{Rj})=\mathbf{R f}+[\mathrm{E}(\mathrm{Rm})-\mathrm{Rf}] \boldsymbol{\beta j}$

Perhitungan yang dilakukan sebelumnya :

$$
\begin{array}{ll}
E(R m) & =\frac{\sum R m}{n} \\
E(R j) & =\frac{\sum R j}{n} \\
\operatorname{Cov}(R m 1 R j) & =\sum[R m-E(R m)][R j-E(R j)]
\end{array}
$$


$\mathrm{Bj}=$ Var Rm

b. Return On Investment (ROI)adalah rasio untuk mengukur kemampuan perusahaan dengan keseluruhan dana yang ditanamkan dalam aktiva yang digunakan untuk operasi perusahaan dalam menghasilkan keuntungan atau profitabilitas. Rasio ini dapat dihitung dengan rumus :

\section{ROI = Laba bersih setelah Pajak} Total Aktiva

c. Return On Asset (ROA) merupakan ratio untuk mengukur kemampuan perusahaan dalam menghasilkan laba bersih sebelum pajak.

\section{$R O A=\underline{\text { Laba Bersih }}$ Total Aktiva}

d. Return On Equity (ROE) adalah salah satu ratio profitabilitas untuk mengukur keefektifitasan perusahaan beroperasi sehingga menghasilkan keuntungan.

Diformulasikan sebagai berikut :

ROE = Laba bersih setelah bunga dan Pajak

Total Modal Sendiri (Ekuitas)

e. Debt to Equity Ratio (DER) adalah rasio yang menunjukkan perbandingan antara pembiayaan dan pendanaan melalui hutang, nilai $D E R$ ditunjukkan dengan total debts yang dibagi dengan nilai total shareholders equity.

Diformulasikan sebagai berikut :

\section{$D E R=\underline{\text { Total Kewajiban }}$}




\section{Total Ekuitas}

f. Earning Pershare (EPS) merupakan salah satu rasio profitabilitas yang berhubungan dengan kepentingan bagi pemegang saham dan manajemen di saat ini maupun yang akan datang.

Diformulasikan sebagai berikut :

\section{$E P S=$ Laba Bersih setelah Pajak Jumlah Lembar Saham}

\subsection{Metode Pengumpulan Data}

Prosedur dan metode yang digunakan untuk pengumpulan data pada penelitian ini adalah :

1. Pengumpulan Data Sekunder

Penelitian ini menggunakan data sekunder yang diperoleh dari beberapa sumber, yaitu laporan keuangan perusahaan - perusahaan dari situs Bursa Efek Indonesia.

2. Penelitian Kepustakaan (Library Research)

Penelitian Kepustakaan dilakukan untuk memperoleh landasan teoritis yang dapat menunjang dan dapat digunakan sebagai tolak ukur pada penelitian ini. Penelitian kepustakaan ini dilakukan dengan cara membaca, menelaah, dan meneliti literatur - literatur yang tersedia seperti buku, jurnal, makalah dan artikel.

3. Data harga saham dari tahun 2011 - 2016 untuk menghitung returnsaham. Harga saham yang digunakan adalah harga saham pada saat penutupan (closing price)

\subsection{Teknik Penentuan Populasi dan Sampel}

Populasi pada penelitian ini adalah perusahaan Oil\&Gas yang listing di Bursa Efek Indonesia pada tahun 2011 - 2016 dengan menggunakan data panel pada penelitian. Sementara itu, sampel dipilih dengan metode purposive 
sampling yaitu teknik penentuan sampel dengan pertimbangan atau dengan kriteria pemilihan tertentu. Adapun kriteria - kriteria tersebut :

1. Perusahaan OIL \& GAS yang terdaftar di Bursa Efek Indonesia dalam periode tahun $2011-2016$.

2. Secara konsisten mempublikasikan laporan keuangan setiap tahunnya.

3. Laporan keuangan yang digunakan sebagai sample adalah laporan keuangan per 31 Desember tahun 2011 - 2016, karena laporan tersebut telah diaudit sehingga informasi yang dilaporkan dsapat lebih dipercaya.

\subsection{Metode Analisis Data}

Metode analisis yang digunakan dalam penelitian ini adalah metode analisis regresi berganda. Dalam analisis regresi, selain mengukur kekuatan hubungan antara dua variabel atau lebih, juga menunjukan arah hubungan antara variabel dependen dengan independen (Winarno, 2009: 6.1).

Penelitian ini menggunakan program Eviews 8.0 untuk melakukan uji statistik deskriptif dengan menggunakan mean, median, standar deviasi, maksimum dan minimum. Uji asumsi klasik dengan melakukan uji normalitas, uji heteroskedastisitas, uji multikolinearitas, dan uji autokorelasi baru kemudian akan dilakukan uji hipotesis, yaitu uji $t$.

\subsubsection{Analisis Model Regresi Data Panel}

Untuk menguji pengaruh variabel-variabel bebas terhadap variabel terikat dibuat persamaan regresi berganda sebagai berikut:

$$
Y=\alpha+\beta 1 E V A+\beta 2 R O I+\beta 3 R O A+\beta 4 R O E+\beta_{5} D E R+\beta 6 E P S+e
$$

Dimana :

$$
\begin{aligned}
& Y=\text { Return Saham } \\
& E V A=\text { Economic Value Added } \\
& R O I=\text { Return On Invesment }
\end{aligned}
$$




$$
\begin{aligned}
& R O A=\text { Return On Assets } \\
& R O E=\text { Return On Equity } \\
& D E R=\text { Debt To Equity Ratio } \\
& E P S=\text { Earning Per Share } \\
& \beta 1-\beta 6 \quad=\text { Koefisien Regresi } \\
& \mathrm{e} \quad=\text { Error }
\end{aligned}
$$

Dalam persamaan garis regresi, yang bertindak sebagai variabel dependent adalah return saham, sedangkan variabel independen diwakili oleh Economic Value Added (EVA), Return On Invesment (ROI), Return On Assets (ROA), Return On Equity (ROE), Debt To Equity Ratio (DER), Earning Per Share (EPS). Alat analisis regresi berganda digunakan untuk mengukur pengaruh dari gabungan variabel - variabel Economic Value Added (EVA), Return On Invesment (ROI), Return On Assets (ROA), Return On Equity (ROE), Debt To Equity Ratio (DER), Earning Per Share (EPS).

Penelitian ini menggunakan data panel, yaitu gabungan antara data silang (cross section) dengan data runtut waktu (time series). Keuntungan yang diperoleh dengan menggunakan data panel, yaitu mampu menyediakan data yang lebih banyak sehingga akan menghasilkan derajat kebebasan (degree of freedom) yang lebih besar yang dikarenakan data panel merupakan gabungan data dari cross section dan time series. Data Panel dapat memberikan informasi lebih banyak yang tidak dapat diberikan hanya oleh data cross section atau time series saja.

Jika setiap unit cross section mempunyai data time series yang sama maka modelnya disebut model regresi data panel seimbang (balance panel). Sedangkan jika jumlah observasi time series dari unit cross section tidak sama maka regresi panel data tidak seimbang (unbalance panel). Penelitian ini menggunakan regresi unbalance panel. 
Terdapat tiga pendekatan dalam mengestimasi model regresi dengan data panel (Winarno, 2009:9.14). Ketiga pendekatan tersebut yaitu:

\section{Common Effect}

Pendekatan common effect yaitu pengabungan data times series dan cross section tanpa melihat perbedaan waktu. Model ini adalah jenis data panel yang paling sederhana. Dikatakan sederhana karena dalam model ini intercept dan slope diestimasikan konstan untuk seluruh observasi. Metode yang digunakan untuk mengestimasi model ini yaitu dengan menggunakan Ordinary Least Square (OLS). Dalam pendekatan ini diasumsikan bahwa perilaku data antar perusahaan sama dalam berbagai kurun waktu.

\section{Fixed Effect}

Pendekatan fixed effect yaitu efek pendekatan yang menyatakan bahwa satu objek memiliki konstan yang tetap besarnya untuk berbagai periode waktu demikian juga dengan koefisien regresinya yang besarnya tetap dari waktu ke waktu (Winarno, 2009 : 9.15). Untuk membedakan satu obyek dengan obyek lainnya digunakan variabel semu (dummy).

3. Random Effect

Random effect ini digunakan untuk mengatasi kelemahan metode fixed effect yang menggunakan variabel semu, sehingga model mengalami ketidakpastian. Tanpa menggunakan variabel semu, metode random effect menggunakan residual, yang diduga memiliki hubungan antarwaktu dan antarobjek (Winarno, 2009: 9.17)

\subsubsection{Uji Model Pendekatan Estimasi Panel}

Untuk menentukan model mana yang paling tepat digunakan dalam penelitian ini, maka harus dilakukan beberapa pengujian, antara lain :

1. Uji Chow

Uji chow ini digunakan untuk memilih pendekatan model panel data apakah menggunakan common effect atau fixed effect.

Hipotesis untuk pengujian ini adalah: 


$$
\begin{aligned}
\mathrm{H}_{0} & =\text { Model menggunakan common effect } \\
\mathrm{H}_{1} & =\text { Model menggunakan fixed effect }
\end{aligned}
$$

$\mathrm{H}_{0}$ diterima apabila nilai probabilitas Chi-square $>0.05$ (tidak signifikan). Sebaliknya apabila nilai probabilitas Chi-square< 0.05 (signifikan), maka $\mathrm{H}_{1}$ diterima atau $\mathrm{H}_{0}$ ditolak.

2. Uji Hausman

Uji hausman digunakan untuk memilih pendekatan model panel data apakah menggunakan fixed effect atau random effect. Hipotesis untuk pengujian ini adalah:

$\mathrm{H}_{0}=$ Model menggunakan fixed effect

$\mathrm{H}_{1}=\quad$ Model menggunakan random effect

$\mathrm{H}_{0}$ diterima apabila nilai probabilitas Chi-square $>0.05$ (tidak signifikan). Sebaliknya apabila nilai probabilitas Chi-square< 0.05 (signifikan), maka $\mathrm{H}_{1}$ diterima atau $\mathrm{H}_{0}$ ditolak

\subsubsection{Uji Statistik Deskriptif}

Statistik deskriptif digunakan untuk mendeskripsikan variabel variabel dalam penelitian ini. Alat analisis yang digunakan adalah rata rata (mean), standar deviasi, maksimum dan minimum. Statistik deskriptif menyajikan ukuran - ukuran numeric yang sangat penting bagi data sampel.

\section{HASIL DAN PEMBAHASAN}

\section{Pengaruh variable Economic Value Added(EVA) terhadap return saham}

Variabel Economic Value Addeddigunakan untuk mengukur nilai tambah (value added) yang dihasilkan suatu perusahaan dengan cara mengurangi beban biaya modal (cost capital) yang timbul sebagai akibat investasi yang dilakukan.Dalam penelitian ini, uji hipotesis variabel ini sebagai berikut: 


\section{$H_{1}$ : EVA berpengaruh positif terhadap return saham.}

Hasil analisis menunjukkan bahwa variabelEconomic Value Added(EVA) signifikan pada alfa lima persen dengan tanda koefisien yang positif yaitu sebesar 0,371 . Ini berarti hipotesis alternatif $(\mathrm{H} 1)$ yang diajukan diterima dan menolak $\mathrm{H}_{0}$. Tanda dari hasil analisis ini telah sesuai dengan uji hipotesis yang diajukan yaitu bertanda positif dan berpengaruh. Dengan demikian, semakin besar Economic Value Added perusahaanOIL \& GAS di Indonesia diikuti dengan perubahan return saham yang diperoleh perusahaan.

Hasil yang positif dan signifikan terhadap return saham sesuai dengan penelitian Ansori (2015) di mana menemukan bahwa terdapat hubungan positif dengan return saham. Pengaruh yang positif dan signifikan ini dikarenakan dengan semakin tinggi nilai Economic Value Addedmaka harga saham akan mengalami kenaikan yang pada akhirnya memberikan return saham yang tinggi.

Lebih lanjut, Anggrahini (2014) dan Janitra \& Kesuma (2015) menunjukkan hasil yang berbeda dengan penelitian ini. Dalam penelitian mereka Economic Value Addedtidak berpengaruh signifikan terhadap return saham.

\section{Pengaruh variabel Return On Invesment (ROI) terhadap return saham}

Variabel ini merupakan rasio dari kemampuan perusahaan dengan keseluruhan dana yang ditanamkan dalam aktiva yang digunakan untuk operasi perusahaan dalam menghasilkan keuntungan atau profitabilitas. Dalam penelitian ini, uji hipotesis variabel ini sebagai berikut:

\section{$\mathrm{H}_{2}$ : $R O$ I berpengaruh positif terhadap return saham.}

Hasil analisis menunjukkan bahwa variabel Return On Invesment $(R O I)$ signifikan pada alfa lima persen dengan tanda koefisien yang positif yaitu sebesar 1,763. Ini berarti hipotesis alternatif $(\mathrm{H} 1)$ yang diajukan diterima dan menolak $\mathrm{H}_{0}$. Tanda dari hasil analisis ini telah sesuai dengan uji hipotesis yang diajukkan yaitu bertanda positif dan berpengaruh. Dengan demikian, semakin besar Return On Invesment ( $R O I)$ perusahaan OIL \& GAS di Indonesia diikuti dengan perubahan return saham yang diperoleh perusahaan. 
Hasil penelitian yang berpengaruh positif dikuatkan dengan Janitra \& Kesuma (2015) dan Anggrahini (2014) di mana $R O I$ berpengaruh positif terhadap return saham. Data statisitik menunjukkan bahwa rata-rata nilai $R O I$ dari perusahaan sampel dalam penelitian ini sebesar 12,31 persen.

\section{Pengaruh variabel Return On Assets (ROA) terhadap return saham}

Variabel ini merupakan rasio dari kemampuan perusahaan atas keseluruhan dana yang ditanamkan dalam aset yang digunakan dalam operasional perusahaan untuk menghasilkan laba. Semakin tinggi $R O A$, maka akan menunjukkan semakin efisien operasional dari suatu perusahaan, begitupun sebaliknya rendahnya $R O A$ dapat disebabkan oleh banyaknya aset perusahaan yang menganggur, investasi dalam persediaan yang terlalu banyak, kelebihan uang kertas, aset tetap beroperasi di bawah normal dan lain - lain.Dalam penelitian ini, uji hipotesis variabel ini sebagai berikut:

\section{$\mathrm{H}_{3}$ : $\mathrm{ROA}$ berpengaruh positif terhadap return saham.}

Hasil analisis menunjukkan bahwa variabelreturn on asset (ROA) signifikan pada alfa lima persen dengan tanda koefisien yang negatif yaitu sebesar 1,604. Ini berarti hipotesis alternatif $(\mathrm{H} 1)$ yang diajukan ditolak dan menerima $\mathrm{H}_{0}$. Tanda dari hasil analisis ini tidak sesuai dengan uji hipotesis yang diajukkan yaitu bertanda positif dan berpengaruh. Hasil penelitian ini sesuai dengan penelitian Pulungan \& Yunita (2015) dimana ROA berpengaruh tidak signifikan terhadap return saham. Dengan demikian, semakin besar return on asset (ROA) perusahaan OIL \& GAS di Indonesia diikuti dengan perubahan return saham yang menurun. $R O A$ yang berpengaruh negatif menunjukkan bahwa pengelolaan perusahaan kurang efisien sehingga investor menilai kinerja perusahaan kurang baik dan menyebabkan harga saham menjadi turun dan kemudian berdampak pada return saham yang ikut menurun.

\section{Pengaruh variabel Return On Equity $(R O E)$ terhadap return saham}


Return on equity $(R O E)$ merupakan rasio yang merefleksikan seberapa banyak perusahaan telah memperoleh hasil atas dana yang telah diinvestasikan oleh pemegang saham (baik secara langsung maupun dengan laba yang ditahan). ROE sering disebut rate of returnon net worth, yaitu kemampuan perusahaan dalam menghasilkan keuntungan dengan modal sendiri yang dimiliki. Laba yang diperhitungkan adalah laba bersih dipotong dengan pajak atau Earning After Tax (EAT). Dalam penelitian ini, uji hipotesis variabel ini sebagai berikut:

\section{$\mathrm{H}_{4}$ : $\mathrm{ROE}$ berpengaruh negatif terhadap return saham.}

Hasil analisis menunjukkan bahwa variabel return on equity $(R O E)$ tidak signifikan pada alfa lima persen dengan tanda koefisien yang positif yaitu sebesar 0,075. Ini berarti hipotesis alternatif $(\mathrm{H} 1)$ yang diajukan ditolak dan menerima $\mathrm{H}_{0}$. Tanda dari hasil analisis ini sesuai dengan uji hipotesis yang diajukkan yaitu bertanda positif. Dengan demikian, semakin besar return on equity $(R O E)$ perusahaan OIL \& GAS di Indonesia tidak diikuti dengan perubahan return saham yang menurun.

Hasil penelitian yang menolak hipotesis alternatif sesuai dengan beberapa penelitian seperti Pulungan \& Yunita (2016), Anggrahini (2014). Lebih lanjut, Hasil penelitian yang menunjukkan bahwa return on equity tidak berpengaruh terhadap return saham. Ini juga berarti tinggi rendahnya return on equity tidak akan mempengaruhi investor dalam pengambilan keputusan investasinya, karena apabila perusahaan mampu mengelola modalnya dengan baik maka akan mampu menghasilkan profit. Maka tidak semua perusahaan yang modalnya menurun akan berpengaruh pada return saham perusahaan tersebut.

\section{Pengaruh variabel Debt to Equity Ratio(DER) terhadap return saham}

Debt to equity ratio (DER), merupakan kelompok rasio solvabilitas yang menjadi salah satu variabel independen dalam penelitian ini. Nilai $D E R$ ditunjukkan dengan total debts yang dibagi dengan nilai totalshare holders equity. Ang (1997) menjelaskan bahwa semakin tinggi $D E R$ menunjukkan semakin besar total hutang terhadap total ekuitas. Hipotesis penelitian yang diajukkan dalam penelitian ini yaitu

\section{$\mathrm{H}_{5}$ : $D E R$ berpengaruh negatif terhadap return saham.}


Hasil analisis menunjukkan bahwa variabeldebt to equity ratio $(D E R)$ signifikan pada alfa lima persen dengan tanda koefisien yang negatif yaitu sebesar 0,483. Ini berarti hipotesis alternatif $(\mathrm{H} 1)$ yang diajukan diterima dan menolak $\mathrm{H}_{0}$. Tanda dari hasil analisis ini sesuai dengan uji hipotesis yang diajukkan yaitu bertanda negatif. Dengan demikian, semakin besar debt to equity ratio (DER) perusahaan OIL \& GAS di Indonesia diikuti dengan perubahan return saham yang semakin menurun.

Hasil penelitian sesuai dengan penelitian Puspitadewi \& Rahyuda (2016), dan Aufa (2013) yang menunjukan hasil bahwa DER berpengaruh negatif terhadap return saham.

\section{Pengaruh Variabel Earning Per Share (EPS) terhadap return saham}

Earningper share (EPS) merupakan perbandingan antara laba bersih setelah pajak pada satu tahun buku dengan jumlah saham yang diterbitkan (Widiatmojo, 1996 dan Martono, 2009). Kenaikan earning per share berarti perusahaan sedang dalam tahap pertumbuhan atau kondisi keuangannya sedang mengalami peningkatan dalam penjualan dan laba, atau dengan kata lain semakin besar earning per share menandakan kemampuan perusahaan dalam menghasilkan keuntungan bersih setiap lembar saham. Hipotesis penelitian yang diajukkan dalam penelitian ini yaitu

\section{$\mathrm{H}_{6}$ : EPS berpengaruh positif terhadap return saham.}

Hasil analisis menunjukkan bahwa variabeldebt to equity ratio (DER) tidak signifikan pada alfa lima persen dengan tanda koefisien yang negatif yaitu sebesar 0,440 . Ini berarti hipotesis alternatif $(\mathrm{H} 1)$ yang diajukan ditolak dan menerima $\mathrm{H}_{0}$. Tanda dari hasil analisis ini tidak sesuai dengan uji hipotesis yang diajukkan yaitu bertanda negatif. Dengan demikian, semakin besar debt to equity ratio (DER) perusahaan OIL \& GAS di Indonesia tidak mempengaruhi return saham perusahaan minyak dan gas di Indonesia.

Kondisi ini menunjukkan bahwa nilai earning per share menurun karena peroleban laba mengalami naik turun yang disebabkan pada tahun 2010-2014 perekonomian pasar dalam keadaan tidak stabil, Sedangkan jumlah saham yang 
beredar tetap. Oleh sebab itu, pihak investor kurang mempertimbangkan EPS dalam membeli saham suatu perusahaan. Hasil penelitin ini tidak mendukung penelitian yang dilakukan Anggrahini (2014) tentang Pengaruh ROI, ROE, EPS dan EVA terhadap Return Saham Perusahaan Manufaktur yang terdaftar di Bursa Efek Indonesia Periode 2009-2011. Hasil penelitian secara parsial menunjukkan bahwa variabel EPS berpengaruh signifikan terhadap return saham.

\section{KESIMPULAN DAN SARAN}

\section{Kesimpulan}

Berdasarkan hasil penelitian dan pembahasan dapat disimpulkan sebagai berikut:

1. VariabelEconomic Value Added berpengaruh positif terhadap returnsaham pada perusahaan minyak dan gas yang terdaftar dalam BEI

2. VariabelReturn On linvesment $(R O I)$ berpengaruh positif terhadap returnsaham pada perusahaan minyak dan gas yang terdaftar dalam BEI

3. VariabelReturn On Asset(ROA) berpengaruh negatif terhadap returnsaham pada perusahaan minyak dan gas yang terdaftar dalam BEI

4. VariabelReturn On Equity ( $R O E$ ) tidak berpengaruh terhadap returnsaham pada perusahaan minyak dan gas yang terdaftar dalam BEI

5. Variabel Debt To Equity Ratio(DER) berpengaruh negatif terhadap returnsaham pada perusahaan minyak dan gas yang terdaftar dalam BEI

6. VariabelEarning Per Share(EPS) tidak berpengaruh terhadap returnsaham pada perusahaan minyak dan gas yang terdaftar dalam BEI

\section{Saran}

Berdasarkan hasil pembahasan dan simpulan yang diperoleh dalam penelitian ini, maka saran yang dapat diberikan sebagai berikut: 
1. Bagi investor hendaknya mempertimbangkan faktor internal keuangan perusahaan terutama faktor-faktor internal yang menjadi fundamental berpengaruh terhadap return saham.

2. Untuk penelitian selanjutnya sebaiknya perlu menambahkan faktor eksternal yang berpengaruh terhadap return saham, dikarenakan masih ada sisa $64,40 \%$ faktor diluar model penelitian ini yang belum dimasukkan.

\section{DAFTAR PUSTAKA}

Ang, Robert, (1997), Buku Pintar Pasar Modal Indonesia (The Intelligent Guide to Indonesian Capital Market), Jakarta: Mediasoft Indonesia.

Arif, S. \&amp; Edy, U. (2008). Panduan Praktis dan Dasar Analisis Laporan Keuangan. Jakarta: Grasindo.

Arista, Desy \&amp; Astohar. (2012). "Analisis Faktor - faktor yang Mempengaruhi Return Saham (Kasus pada Perusahaan Manufaktur yang Go Public di BEI periode tahun 2005 - 2009). Jurnal IImu Manajemen dan Akuntansi Terapan, Volume 3 Nomor 1.

Badriah, Siti \&amp; Sugiarto, Toto. (2011). Analisis Hubungan Economic Value Added (EVA) Dengan MarketValue Added (MVA) Pada Perusahaan Manufaktur Sektor Barang Konsumsi dan Telekomunikasi yang Terdaftar Dalam LQ45.

Brigham, E.F., \&amp; Joel. F.H,(2006), Dasar - Dasar Manajemen Keuangan, Edisi Keenam. Jakarta: Penerbit Salemba Empat.

Brigham, E.F dan Joel F.H. (2010). Manajemen Keuangan, Buku I, Edisi Kesepuluh. Jakarta: Penerbit Salemba Empat.

Brigham, E.F dan Joel F.H. (2011). Dasar-Dasar Manajemen Keuangan, Buku 2, Edisi Kesebelas. Jakarta: Penerbit Salemba Empat.

Darsono, Azhari. (2005). Pedoman Praktis Memahami Laporan Keuangan. Yogyakarta: Andi. 
Harahap, S.S. (2004). Analisis Kritis atas Laporan Keuangan. Jakarta: PT Raja GrafindoPersada.Ikatan Akuntan Indonesia. (2007). Standar Akuntansi Keuangan. PenerbitSalemba Empat, Indonesia.

Jogiyanto. 2000. Teori Portofolio dan Analisis Investasi, Yogyakarta: BPF-UGM. 